\title{
Liquid Whey Protein Concentrates Produced by Ultrafiltration as Primary Raw Materials for Thermal Dairy Gels
}

\author{
Marta Henriques ${ }^{1,2 *}$, David Gomes ${ }^{1,2}$ and Carlos Pereira ${ }^{1,2}$ \\ ${ }^{1}$ Polytechnic Institute of Coimbra, College of Agriculture, Bencanta, PT-3045-601 Coimbra, Portugal \\ ${ }^{2}$ Research Centre for Natural Resources, Environment and Society (CERNAS), College of Agriculture, \\ Polytechnic Institute of Coimbra, Bencanta, PT-3045-601 Coimbra, Portugal \\ Received: March 8, 2017 \\ Accepted: July 21, 2017
}

\begin{abstract}
Summary
The aim of this work is to study the gelation properties of liquid whey protein concentrates (LWPC) produced by ultrafiltration (UF) as raw material for thermally induced gels intended for food applications. LWPC thermal gelation was performed using different types of LWPC (non-defatted, defatted and diafiltered) of different protein mass fractions and $\mathrm{pH}$. Most of the produced gels showed viscoelastic behaviour. Non-defatted LWPC gave stronger heat-induced gels with a more cohesive microstructure, a higher water holding capacity and also higher elastic modulus ( $\left.G^{\prime}\right)$ and viscous modulus (G"). Gel properties were not improved in products with lower content of non-protein compounds. As expected, the increase in protein mass fraction positively influences protein interactions. However, the $\mathrm{pH}$ is responsible for the equilibrium between attraction and repulsion forces in the gel components that influence gel hardness and water holding capacity.
\end{abstract}

Key words: liquid whey protein concentrate, thermally induced gel, water holding capacity, microstructure, rheology

\section{Introduction}

Dry whey protein concentrates (WPC) or isolates (WPI) have become well established as food ingredients and applications have been found across a wide range of food products. Their nutritional and functional properties have been extensively reviewed and reported in the literature (13). Although dehydrated whey protein products with high protein content (i.e. WPC and WPI) have been studied extensively, no attention has been paid to the functionality of liquid whey protein concentrates used as such.

Among the functional properties of whey proteins, gelation is cited as one of the most interesting hydration-related properties (4). Gels consist mostly of fluid, but have the remarkable ability to behave as a solid whilst retaining many properties characteristic of the fluid component. Gelation is a two-step process involving protein denaturation and aggregation (5). During heat treatment, the intramolecular bonds of proteins responsible for their secondary and tertiary structures (hydrogen and disulphide bonds) break down and expose the hydrophobic groups and cysteine residues, which are located in the inner region of native proteins, whilst the primary structure of the protein is maintained. This phenomenon is called protein denaturation. Protein aggregation or polymerization corresponds to the formation of a three-dimensional network by the establishment of intermolecular bonds between the exposed groups of denatured proteins. Heat-induced protein denaturation is the easiest method to achieve protein gelation.

Several intrinsic and extrinsic factors affecting the gelation of whey proteins, as well as the type and properties of gels have been investigated. These include the protein type (molecular mass and amino acid composition) (6), protein hydrophobicity and free sulphydryl groups (7), protein concentration (8), the proportions of individual whey proteins in the mixture (9), the type and amount of salts $(8,10,11)$, lipids (12), lactose (6), sucrose (13) present in the formula-

"Corresponding author: Phone: +351 239802 940; Fax: +351 239802 979; E-mail: mhenriques@esac.pt ORCID IDs: 0000-0001-9214-0614 (Henriques), 0000-0001-7916-9906 (Gomes), 0000-0003-1705-2301 (Pereira) 
tion, process conditions ( $\mathrm{pH}$, temperature, heating and cooling rate) $(14,15)$, and/or specific treatments such as microparticulation of whey proteins (16-18). Among these factors, attention has been focused on protein concentration and $\mathrm{pH}$. The cross-linking of macromolecules of an arbitrary initial size distribution is required for gelation and is proportional to their protein concentration. There must also be a minimal concentration of the protein itself, below which a continuous three-dimensional structure cannot be formed. However, the minimum protein concentration needed to form a gel also correlates with the $\mathrm{pH}$ (in particular with the isoelectric point ( $\mathrm{pI}$ ) of proteins). The more the $\mathrm{pH}$ moves away from the pI of proteins, the more charged they become and a greater electrostatic repulsion occurs between molecules, preventing the interactions required to form a gel matrix (19). This implies that at $\mathrm{pH}=4.5$ (close to the $\mathrm{pI}$ of whey proteins) the minimum whey protein mass fraction is $4 \%$, at $\mathrm{pH}=6$ between $6-8 \%$ and at $\mathrm{pH}=7$ (far from the $\mathrm{pI}$ ) the protein mass fraction increases to $8-12 \%(20)$.

The gel structure determines the water holding capacity, permeability, texture and appearance of the gel (21). The knowledge of the rheological or mechanical properties of the system is very important, since the physical attributes of food, including the lack of visual liquid separation and the perceived viscosity, are crucial aspects of quality and overall sensory acceptance by the consumers $(22,23)$.

Small and medium cheese producers usually deliver the whey they produce to large industries that normally apply several concentration steps (ultrafiltration (UF) and/or diafiltration) followed by drying for the production of WPC or WPI. However, small and medium units may directly reutilize the whey produced by introducing a selective concentration step by means of UF, followed by direct utilization of the obtained UF retentates, which can be denominated liquid whey protein concentrates (LWPC).

This study intends to investigate the gelation properties of such LWPC obtained at different manufacturing stages, namely non-defatted, defatted and diafiltered, as low-cost alternatives to conventional dried WPC and WPI products.

In the preparation of the thermal gels, protein denaturation was achieved exclusively by heat treatment, and the influence of protein mass fraction and $\mathrm{pH}$ was evaluated in terms of water holding capacity, rheological behaviour (small- and large-strain properties) and microstructure of the gels.

\section{Materials and Methods}

\section{Materials}

Bovine cheese whey was supplied by a medium size cheese producer Queijaria Serqueijos SA (Rabaçal, Portugal). All the chemicals used were of analytical grade.

\section{LWPC manufacture}

For the production of liquid whey protein concentrates (LWPC), $600 \mathrm{~L}$ of bovine cheese whey obtained immediately after production were transported in metallic recipients $(50 \mathrm{~L})$ at ambient temperature to the pilot plant at the Escola Superior Agrária de Coimbra (Portugal). The resting time between leaving the production plant and arriving at the pilot plant was less than $2 \mathrm{~h}$, in order to minimise product deterioration. On reception, the cheese fines were removed by filtration using a cloth filter. A volume of $300 \mathrm{~L}$ of whey was skimmed in a Westfalia ${ }^{\mathrm{TM}}$ separator type ADB (Westfalia Separator, Oelde, Germany) in order to reduce the fat content in the final products. The remaining whey (300 L) was used directly for ultrafiltration (UF). Each type of whey (non-defatted and defatted) was concentrated using conventional UF with a volumetric concentration factor (VCF) of 20. The process was performed with an ultrafiltration batch equipment (Proquiga Biotech S.A., La Coruña, Spain) using an organic UF membrane DSS (model 20K 3838-30) with a $5.5 \mathrm{~m}^{2}$ effective filtration area and a 20-kDa cut-off (Iberlact SL, Madrid, Spain) at $40-45^{\circ} \mathrm{C}$. In the diafiltration, the main purpose of which was to reduce the presence of lactose and salts, half of the retentate from ultrafiltration $(7.5 \mathrm{~L})$ of defatted whey was diluted with water $(142.5 \mathrm{~L})$ and then concentrated until the final volume of $15 \mathrm{~L}$ (VCF=10). The following LWPC products were obtained: $(i)$ defatted and (ii) non-defatted, using conventional UF and whey that was defatted or not, respectively, and (iii) diafiltered, when diafiltration was applied. Before preparing the thermal gels, the LWPC products were analysed and frozen at $-15^{\circ} \mathrm{C}$.

\section{Gel preparation}

For thermal gel preparation, each type of LWPC (defatted, non-defatted or diafiltered) was first thawed in a refrigerated chamber $\left(5{ }^{\circ} \mathrm{C}\right)$ and dissolved with distilled water to obtain final protein mass fractions of 5 and $7 \%$. The $\mathrm{pH}$ of each solution was measured and adjusted to 4 and 7 using 0.1 M HCl (PanReac Química SLU, Barcelona, Spain) or $0.1 \mathrm{M} \mathrm{NaOH}$ (Fisher Chemical, Waltham, MA, USA) prior to total dilution with water. Each solution was divided into $100-\mathrm{mL}$ plastic cups, sealed with a plastic rack and heated in a water bath at $80{ }^{\circ} \mathrm{C}$ for $30 \mathrm{~min}$. After heat treatment, the solutions were cooled in an ice bath to $20-25^{\circ} \mathrm{C}$. This step took less than $2 \mathrm{~h}$, and then the samples were transferred to a refrigerated chamber $\left(5^{\circ} \mathrm{C}\right)$. The gels were prepared in triplicate and physicochemical and rheological properties of the samples were evaluated after $24 \mathrm{~h}$ of storage.

\section{LWPC and gel compositional analyses}

After production, the three types of LWPC (defatted, non-defatted or diafiltered) as well as the thermal gels were analysed in triplicate, and mass fractions of total solids, fat, total protein, ash and lactose were determined. The $\mathrm{pH}$ of the samples was directly determined with a radiometer PHM61 laboratory $\mathrm{pH}$ meter (A/S Copenhagen, Copenhagen, Denmark) immediately after production. The titratable acidity of the LWPC, expressed in percentage of lactic acid, was determined by titration using $0.1 \mathrm{M} \mathrm{NaOH}$ (Fisher Chemical) in an automatic titrator model 665 Dosimat (Metrohm AG, Herisau, Switzerland) following Portuguese standards used for milk (24) and thermal gels (25). Total solids were determined by oven drying the samples for $6 \mathrm{~h}$ (Universal Oven U15; Memmert GmbK+Co. KG, Schwabach, Germany) and mass was weighed on an analytical bal- 
ance (model TE 214S; Sartorius, Frankfurt, Germany) (26). The total nitrogen content was determined using the Kjeldahl method (using a digestion unit DK series and a DKL 12 distillation unit both from VELP Scientifica, Usmate, Italy) according to ISO 8968-1:2001 (27). The total protein was calculated by multiplying the total nitrogen content of the samples by a factor of 6.38. The fat content of LWPC was determined by the adapted Gerber method (28) and the fat content of the gels by the Gerber method used for yoghurt (29), in both cases using a Gerber K. Schneider \& Co. AG centrifuge (model PM80; Gerber Instruments AG, IllnauEffretikon, Switzerland). The ash content was determined by incinerating dried samples at $550{ }^{\circ} \mathrm{C}$ in an electric muffle furnace model LE 4/11/R6 (Nabertherm GmbH, Lilienthal, Germany) according to AOAC (30). The remaining solids (most of which was lactose) were determined by the difference between the total solid content of the samples and the sum of the ash, fat and protein contents.

\section{Gel physicochemical analyses}

\section{Water holding capacity}

Water holding capacity of the gels was determined using the method applied by Henriques et al. (31) and calculated as the ratio of the mass of water held in the gels after centrifugation to the initial mass of the gels (expressed in \%). Analyses were performed in triplicates.

\section{Small-strain rheological properties}

A controlled stress rheometer Haake ${ }^{\mathrm{TM}}$ Rheostress ${ }^{\mathrm{TM}}$ 1 (Thermo Fisher Scientific, Karlsruhe, Germany) was used to determine the rheological properties of the gels, in oscillatory mode. The system consisted of a plate/cone measuring geometry P35 Ti Ls-C35/1 ${ }^{\circ} \mathrm{Ti} \mathrm{L}(35 \mathrm{~mm}$ diameter and $1^{\circ}$ angle; HAAKE MARS, Thermo Fisher Scientific). The gap between the cone and plate was maintained at $0.052 \mathrm{~mm}$. Stress sweep tests were conducted at a frequency of $1 \mathrm{~Hz}$ to investigate the rheological linear viscoelastic behaviour of gels. The rheological properties, elastic modulus $\left(G^{\prime}\right)$, viscous modulus $\left(G^{\prime \prime}\right)$, complex viscosity $\left(\eta^{*}\right)$ and the damping factor $(\tan \delta)$ of gels were evaluated in the range of $0.05-1.5 \mathrm{~Hz}$ at $3 \mathrm{~Pa}$. All the measurements were done in triplicate.

\section{Large-strain rheological properties - compression test}

Lubricated compression tests were performed using a TA.XT Express enhanced universal texture analyser (Stable Micro Systems Ltd., Godalming, UK) equipped with an acrylic cylindrical probe (50 $\mathrm{mm}$ diameter). Cylindrical gel samples (17 $\mathrm{mm}$ diameter and $15 \mathrm{~mm}$ height) were placed on a flat base and compressed to $10 \mathrm{~mm}$. The pre-test speed and test speed were fixed at 5 and $1 \mathrm{~mm} / \mathrm{s}$, respectively. Each test was performed in triplicate at room temperature (approx. $24{ }^{\circ} \mathrm{C}$ ). Experimental stress-strain curves were generated from the force displacement data, from which strain $\left(\varepsilon_{h}\right)$ and stress $(\sigma)$ were calculated according to Eqs. 1 and 2, respectively:

$$
\varepsilon_{\mathrm{h}}(t)=\ln \left(\frac{h_{0}}{h_{0}-h(t)}\right)
$$

$$
\sigma(t)=\frac{F(t) h(t)}{A_{0} h_{0}}
$$

where $\varepsilon_{\mathrm{h}}(t)$ is the applied strain, $h_{0}$ is the initial height of the specimen $(\mathrm{mm}), h(t)$ is the sample compression distance at any time during the compression test $(\mathrm{mm}), \sigma(t)$ is the applied stress $(\mathrm{Pa}), F(t)$ is the applied force perpendicular to the area of the material at any time during the compression test $(\mathrm{N})$ and $A_{0}$ is the initial cross-sectional area of the sample $\left(\mathrm{m}^{2}\right)$.

Young's modulus $\left(E^{\prime}\right)$ was calculated as the slope of the initial linear region of the stress-strain curves, and the stress at rupture $\left(\sigma_{\text {rup }}\right)$ as the maximum stress value obtained during the compression test, which could be correlated with the hardness of the samples. Analyses were made in triplicate.

\section{Microstructure}

The samples used to analyse the microstructure of the gels were prepared $24 \mathrm{~h}$ after gelation. Gels were cut into cylinders (5 $\mathrm{mm}$ diameter and $10 \mathrm{~mm}$ length) and preserved in a $10 \%$ (by volume) trichloromethane (PanReac Química SLU) solution prior to analysis. Samples were dehydrated for $20 \mathrm{~min}$, each in 30, 50, 70, 90 and 100 \% (by volume) ethanol (PanReac Química SLU). After dehydration, ethanol was replaced by $100 \%$ ketone (Fisher Chemical) and samples were dried to a critical point using $\mathrm{CO}_{2}$ in CDP-020 critical point drier (BAL-TEC AG, Balzers, Liechtenstein). Dried samples were coated with gold-palladium conducting paint (300 $\AA$, at $1200 \mathrm{~V}$ and $10 \mathrm{~mA}$ ) using an ion sputter model JFC-1100 (Jeol, Akishima, Tokyo, Japan). Microstructure was observed in duplicate on a Jeol scanning electron microscope (model JSM-T220 A) at an accelerating voltage of $15 \mathrm{kV}$.

\section{Statistical analysis}

The statistical analysis of the data was carried out using the ANOVA package included in the STATISTICA software v. 12 (32). Mean values were compared using the Tukey's honestly significant difference (HSD) test. Differences were considered significant at $\mathrm{p}<0.05$.

\section{Results and Discussion}

\section{Chemical composition of LWPC}

Table 1 shows the gross chemical composition, $\mathrm{pH}$ and titratable acidity of non-defatted, defatted and diafiltered liquid protein concentrates (LWPC). The total solid content is significantly different $(\mathrm{p}<0.05)$ among products. Diafiltered products had lower values and nondefatted products higher total solid content. As expected, the amount of fat in defatted and diafiltered LWPCs was similar and significantly lower than in the non-defatted LWPC, as a result of fat removal during centrifugation. The protein mass fraction differed significantly $(\mathrm{p}<0.05)$ among products and was lower in non-defatted and higher in diafiltered product. Lower mass fractions of ash and lactose were obtained in diafiltered LWPC. The use of 
Table 1. Gross chemical composition, $\mathrm{pH}$ and titratable acidity of non-defatted, defatted and diafiltered liquid whey protein concentrates

\begin{tabular}{lccc}
\hline & & LWPC & Diafiltered \\
\cline { 2 - 4 } Composition/property & Non-defatted & Defatted & \\
\cline { 2 - 4 } & & $(16.39 \pm 0.14)^{\mathrm{b}}$ & $(15.08 \pm 0.04)^{\mathrm{a}}$ \\
\hline Total solids & $(19.08 \pm 0.08)^{\mathrm{c}}$ & $(0.43 \pm 0.06)^{\mathrm{a}}$ & $(0.60 \pm 0.00)^{\mathrm{a}}$ \\
Fat & $(6.43 \pm 0.35)^{\mathrm{b}}$ & $(9.25 \pm 0.14)^{\mathrm{b}}$ & $(11.93 \pm 0.03)^{\mathrm{a}}$ \\
Proteins & $(7.75 \pm 0.01)^{\mathrm{c}}$ & $(0.71 \pm 0.04)^{\mathrm{b}}$ & $(0.18 \pm 0.02)^{\mathrm{a}}$ \\
Ash & $(0.46 \pm 0.01)^{\mathrm{c}}$ & $(6.06 \pm 0.02)^{\mathrm{b}}$ & $(2.37 \pm 0.03)^{\mathrm{a}}$ \\
Other solids & $(4.45 \pm 0.61)^{\mathrm{c}}$ & $(0.73 \pm 0.01)^{\mathrm{b}}$ & $(1.09 \pm 0.01)^{\mathrm{a}}$ \\
TA (as lactic acid) & $(0.28 \pm 0.00)^{\mathrm{c}}$ & $(5.25 \pm 0.05)^{\mathrm{b}}$ & $(4.62 \pm 0.03)^{\mathrm{a}}$ \\
\hline pH & $(6.43 \pm 0.03)^{\mathrm{c}}$ & &
\end{tabular}

Mean values with the same letter in the same row do not differ significantly $(\mathrm{p}>0.05)$. LWPC=liquid whey protein concentrate, TA=titratable acidity

diafiltration allows greater amounts of lactose and minerals to be eliminated and protein to be concentrated in the retentate.

Titratable acidy (TA) increases as the number of process unit operations increases, since the time required for the entire process allows for the acidification of products by bacterial microflora, and consequently a $\mathrm{pH}$ reduction. For this reason, TA increases from non-defatted to diafiltered products (Table 1).

\section{Gelation properties of LWPC}

The gelation properties of WPC powders are widely reported in the literature $(7,9,11,20)$ but there is no information on the gelation of LWPC directly after production. In order to investigate gelation properties, heat-induced gels were produced. It was observed that liquid whey protein concentrates have attractive gelation properties as well as WPC powders. Depending on the protein mass fraction and $\mathrm{pH}$, it was possible to obtain different structures, ranging from liquid ones, with no capacity to form a gel, to viscoelastic structures.

At $\mathrm{pH}=7$ and $5 \%$ of protein, it was observed that no gel was formed with the diafiltered product and the self-supporting consistency of non-defatted and defatted products was very low (Fig. 1). The lower protein mass fraction (4.76, 4.77 and $4.51 \%$, by mass) observed in these three cases and the higher $\mathrm{pH}$ value may be responsible for this behaviour, although the total solid content of the gels varied between 11.83 and $6.34 \%$ (Table 2). It is well established that a minimum protein mass fraction is needed for gela-

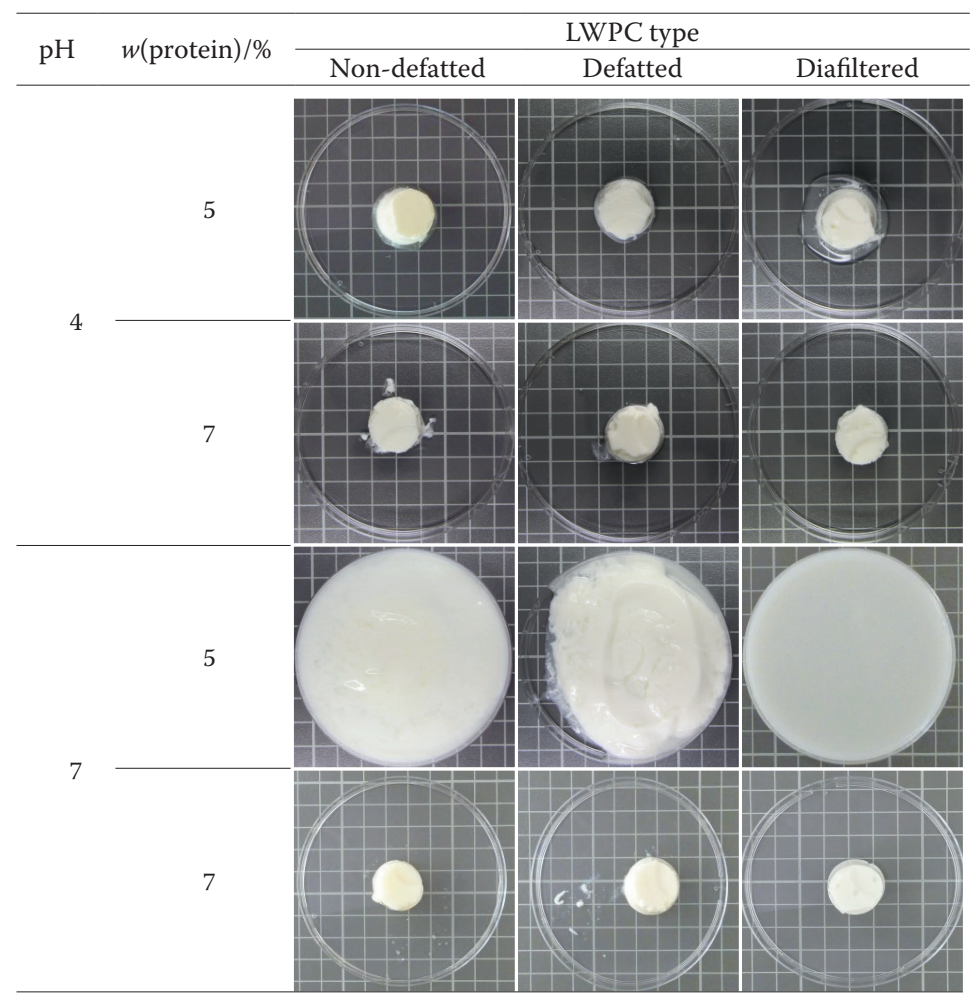

Fig. 1. Appearance of non-defatted, defatted and diafiltered liquid whey protein concentrate (LWPC) thermal gels as a function of $\mathrm{pH}$ and protein mass fraction 
Table 2. Gross composition of non-defatted (ND), defatted (D) and diafiltered (DF) LWPC thermal gels and water holding capacity as a function of $\mathrm{pH}$ and protein mass fraction

\begin{tabular}{|c|c|c|c|c|c|c|c|c|}
\hline \multirow{2}{*}{$\mathrm{pH}$} & \multirow{2}{*}{$\begin{array}{l}\text { Gel } \\
\text { type }\end{array}$} & \multirow{2}{*}{$w($ protein $) / \%$} & \multicolumn{5}{|c|}{$w / \%$} & \multirow{2}{*}{ WHC } \\
\hline & & & Total solids & Proteins & Fat & Ash & Other solids & \\
\hline \multirow{6}{*}{4} & \multirow{2}{*}{ ND } & 5 & $14.35 \pm 0.63$ & $5.55 \pm 0.10$ & $1.50 \pm 0.05$ & $0.43 \pm 0.00$ & $6.87 \pm 0.50$ & $(97.72 \pm 0.89)^{\mathrm{a}}$ \\
\hline & & 7 & $17.96 \pm 0.77$ & $7.64 \pm 0.60$ & $2.20 \pm 0.10$ & $0.85 \pm 0.01$ & $7.26 \pm 0.20$ & $(99.50 \pm 0.47)^{\mathrm{b}}$ \\
\hline & \multirow{2}{*}{$\mathrm{D}$} & 5 & $10.62 \pm 0.49$ & $5.14 \pm 0.25$ & $0.10 \pm 0.06$ & $0.95 \pm 0.34$ & $4.44 \pm 0.30$ & $(94.61 \pm 0.80)^{c}$ \\
\hline & & 7 & $13.70 \pm 0.08$ & $7.65 \pm 0.09$ & $0.20 \pm 0.05$ & $0.79 \pm 0.22$ & $5.06 \pm 0.50$ & $(96.21 \pm 0.64)^{\mathrm{a}}$ \\
\hline & \multirow{2}{*}{ DF } & 5 & $6.76 \pm 0.18$ & $5.16 \pm 0.04$ & $0.10 \pm 0.01$ & $0.31 \pm 0.16$ & $1.19 \pm 0.10$ & $(92.60 \pm 0.92)^{\mathrm{d}}$ \\
\hline & & 7 & $9.41 \pm 0.13$ & $7.34 \pm 0.06$ & $0.10 \pm 0.01$ & $0.43 \pm 0.11$ & $1.54 \pm 0.25$ & $(98.24 \pm 0.73)^{\mathrm{a}}$ \\
\hline \multirow{6}{*}{7} & \multirow{2}{*}{ ND } & 5 & $11.83 \pm 0.37$ & $4.76 \pm 0.07$ & $1.50 \pm 0.06$ & $0.45 \pm 0.00$ & $5.12 \pm 0.50$ & n.d. \\
\hline & & 7 & $17.69 \pm 1.19$ & $7.57 \pm 0.78$ & $1.45 \pm 0.02$ & $0.81 \pm 0.24$ & $7.66 \pm 0.40$ & $(98.80 \pm 1.59)^{\mathrm{ab}}$ \\
\hline & \multirow{2}{*}{$\mathrm{D}$} & 5 & $9.27 \pm 0.24$ & $4.77 \pm 0.10$ & $0.01 \pm 0.00$ & $0.21 \pm 0.01$ & $4.28 \pm 0.35$ & n.d. \\
\hline & & 7 & $14.05 \pm 0.39$ & $7.14 \pm 0.36$ & $0.20 \pm 0.01$ & $0.82 \pm 0.00$ & $5.89 \pm 0.50$ & $(96.06 \pm 0.51)^{\mathrm{a}}$ \\
\hline & \multirow{2}{*}{$\mathrm{DF}$} & 5 & $6.34 \pm 0.10$ & $4.61 \pm 0.00$ & $0.20 \pm 0.04$ & $0.20 \pm 0.04$ & $1.43 \pm 0.10$ & n.d. \\
\hline & & 7 & $9.73 \pm 0.09$ & $7.46 \pm 0.00$ & $0.30 \pm 0.01$ & $0.52 \pm 0.20$ & $1.45 \pm 0.08$ & $(97.92 \pm 0.35)^{\mathrm{a}}$ \\
\hline
\end{tabular}

Mean values with the same letter do not differ significantly ( $>0.05)$. WHC=water holding capacity, n.d.=not determined

tion (33). If the protein mass fraction is lower, intramolecular forces predominate and proteins have no capacity to form an ordered structure, whereas by increasing the amount of proteins in the solution the intermolecular interactions (protein-protein and water-protein) are favoured and gelation occurs (34). Low protein mass fractions (6-8 $\%$ of protein) are cited for gelation using WPC (35), while higher mass fractions (at least $10 \%$ of protein) were needed for WPI gelation (36). At $\mathrm{pH}=7$, our results also corroborate these findings, since products with lower levels of non-protein compounds (such as the diafiltered products), behave like a liquid, indicating that a higher protein mass fraction is needed to form a gel structure under these conditions.

At $\mathrm{pH}=4$, all gels were formed, regardless of the mass fraction of protein. Under these conditions, the lower total solid content of defatted and diafiltered products was due to their lower mass fractions of fat, lactose and minerals but the protein mass fractions were high enough to promote gelation. The fat content of non-defatted gels was lower than of the corresponding LWPC. This difference resulted from fat separation that occurred during the long heat treatment applied for gelation. The separated fat layer was removed from the gels. An appropriate homogenization step at approx. $10^{7} \mathrm{~Pa}$ should have been used in order to overcome this problem.

\section{Rheological properties of the thermal gels}

The rheological properties of the heat-induced LWPC gels were evaluated using an oscillatory rheometer for small-strain rheological properties (Fig. 2), whose statistical analysis is presented in Table 3, and a mechanical compression test for large-strain rheological properties in Table 4.

The elastic modulus $\left(G^{\prime}\right)$ values were higher than the viscous modulus $\left(G^{\prime \prime}\right)$ in all the samples with the excep- tion of the one produced with diafiltered LWPC with $5 \%$ protein at $\mathrm{pH}=7$ (Fig. 2a). This behaviour indicates typical viscoelastic systems (33) and confirms that, given the conditions of the diafiltered sample ( $\mathrm{pH}=7$ and $5 \%$ protein), no gel formation occurred, since $G^{\prime}<G^{\prime}$ '. Tang et al. (37) noted that the viscoelastic behaviour found of whey protein gels (the typical behaviour also shown by our LWPC gels) may be considered the most interesting characteristic for the use of whey protein in food applications. It should be noted that these characteristics are achieved when the protein aggregation step is slower than the protein denaturation step, thus providing enough time for the orderly rearrangement of proteins. In this work the slow cooling procedure was performed in order to avoid disturbance of the gels that could result from shrinkage due to rapid cooling.

The weaker gels were observed at $\mathrm{pH}=7$, regardless of the LWPC product used (Table 3). The lower protein mass fractions ( $<5 \%$ of protein) did not allow for the formation of a solid matrix. The increase in protein mass fraction led to an increase in $G$ ' in the non-defatted and diafiltered gels (Fig. 2a) and also to the formation of a firmer gel, which corroborates the results obtained by other authors $(6,38)$. An exception was found in the case of the defatted gel at $\mathrm{pH}=4$, with a significant decrease in the elastic and viscous modulus (Table 3 ) when the protein mass fraction was increased. The results for G' and G' are in the same range of magnitude of the values found in other works for gels produced with bovine WPC (39-41). However, they are lower than the values found for caprine WPC $(39,42)$ or ovine WPC $(39,43)$ gels. These authors stated that one possible reason for the formation of weaker gels may be the presence of lower amounts of $\beta$-lactoglobulin and the higher ash and lactose contents in bovine WPC. The presence of fat in the gel formulation is cited as a negative influence on gelation. It was also stated that the in- 

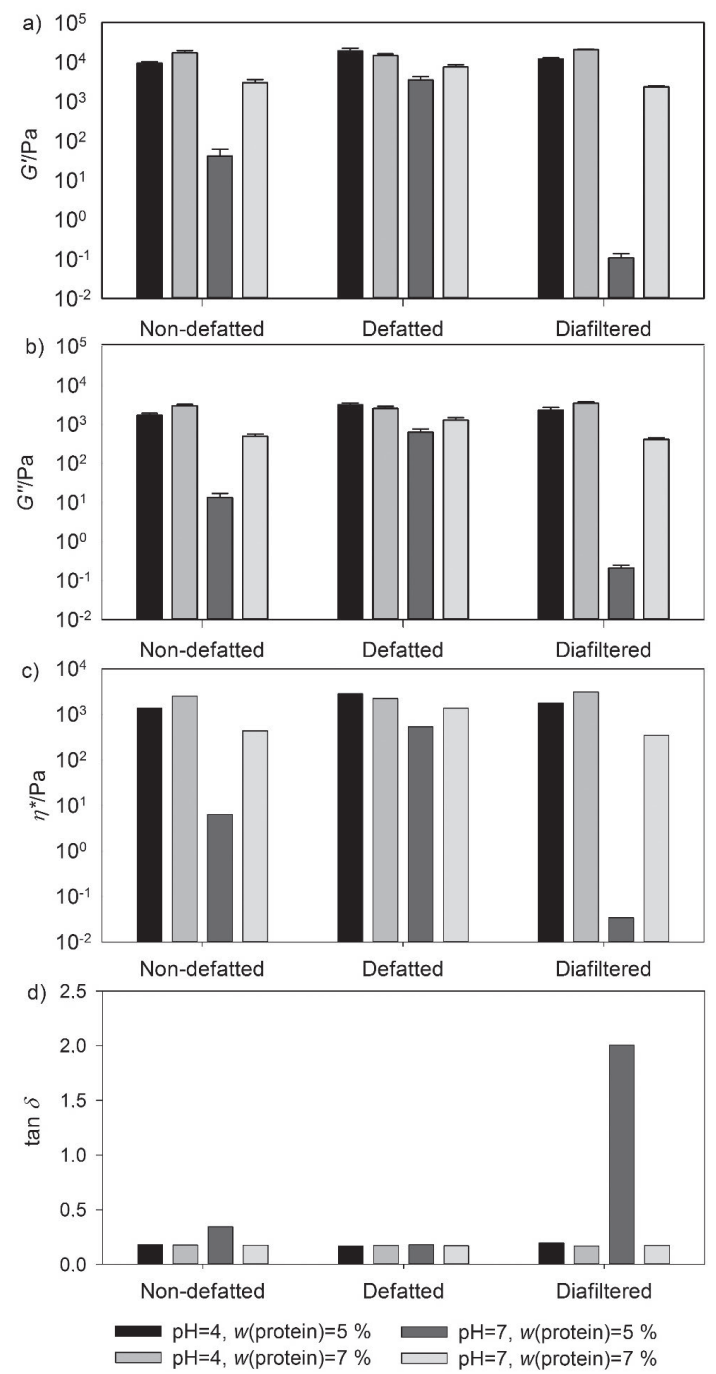

Fig. 2. Results of: a) elastic modulus ( $\left.G^{\prime}\right)$ and viscous modulus $\left(G^{\prime \prime}\right)$, b) complex viscosity $(\eta *)$, and c) damping factor $(\tan \delta)$ of non-defatted, defatted and diafiltered liquid whey protein concentrate (LWPC) thermal gels as a function of $\mathrm{pH}$ ( 4 and 7$)$ and protein mass fraction termolecular forces established between the fat globules and proteins reduce their ability to react with other protein molecules in the formation of the gel network (44). In this research, at small-strain level, no differences in the firmness of the gels were observed between non-defatted and defatted products, especially with regard to those in the proximity of the isoelectric point of whey proteins $(\mathrm{pH}=4)$, which was also verified for caprine gels (42). The complex viscosity ( $\eta^{*}$; Fig. 2c) follows the same behaviour as $G^{\prime}$ and $G^{\prime \prime}$, and the damping factor ( $\tan \delta$; Fig. 2d) also indicates the fluid behaviour of the sample treated at $\mathrm{pH}=7$ with $5 \%$ protein $(\tan \delta>2.0)$ and the stronger gel structure of the remaining samples $(\tan \delta<0.25$; Table 3$)$. It was observed that reducing the non-protein components in the formulation (e.g. lactose and ions) by applying diafiltration did not improve the rheological characteristics of the gels. These results contradict the findings of other authors $(34,45)$, who referred to diafiltration as a good method for improving gel hardness and cohesiveness due to the elimination of lactose. However, the higher protein mass fractions used by them (10\%), as opposed to $7 \%$ in this research, may justify the differences, since the protein interaction in the former case can be more effective.

In the evaluation of large-strain rheological gel properties, only the samples that showed a self-supporting structure (i.e. that were able to maintain their form sufficiently for the compression experiments) were suitable for testing under the conditions defined for this investigation. For this reason, the products prepared with $5 \%$ protein at $\mathrm{pH}=7$ were not appropriate for determining mechanical properties (Table 4). In order to avoid the lack of information about large-strain rheological properties of weak gels, a change in the methodology by applying the immersed gel measurements to the products as referred by Rosenthal (46) is suggested for future works.

A similar trend was observed with regard to stress at rupture $\left(\sigma_{\text {rup }}\right)$ and Young's modulus $\left(E^{\prime}\right)$ for both non-defatted and defatted gels (increasing in line with the protein mass fraction and $\mathrm{pH}$ ). Hardness determined by

Table 3. Mean values and statistical analysis of elastic modulus $\left(G^{\prime}\right)$, viscous modulus $\left(G^{\prime \prime}\right)$, complex viscosity $\left(\eta^{*}\right)$ and damping factor (tan $\left.\delta\right)$ of non-defatted (ND), defatted (D) and diafiltered (DF) LWPC thermal gels as a function of $\mathrm{pH}$ and protein mass fraction

\begin{tabular}{|c|c|c|c|c|c|c|}
\hline $\mathrm{pH}$ & Gel type & $w($ protein $) / \%$ & $G^{\prime} / \mathrm{Pa}$ & G'/Pa & $\eta^{*} / \mathrm{Pa}$ & $\tan \delta$ \\
\hline \multirow{6}{*}{4} & \multirow{2}{*}{ ND } & 5 & $9.379^{c}$ & $1.722^{\mathrm{c}}$ & $1.402^{\mathrm{b}}$ & $0.184^{\mathrm{a}}$ \\
\hline & & 7 & $16.988^{\mathrm{def}}$ & $2.987^{\mathrm{ef}}$ & $2.532^{\text {cd }}$ & $0.177^{\mathrm{a}}$ \\
\hline & \multirow{2}{*}{$\mathrm{D}$} & 5 & $19.056^{\mathrm{ef}}$ & $3.181^{\mathrm{f}}$ & $2.836^{\mathrm{d}}$ & $0.169^{\mathrm{a}}$ \\
\hline & & 7 & $14.474^{\mathrm{d}}$ & $2.565^{\mathrm{de}}$ & $2.160^{c}$ & $0.177^{\mathrm{a}}$ \\
\hline & \multirow{2}{*}{ DF } & 5 & $15.318^{\mathrm{de}}$ & $2.321^{\mathrm{d}}$ & $1.784^{\mathrm{bc}}$ & $0.194^{\mathrm{a}}$ \\
\hline & & 7 & $20.697^{\text {ef }}$ & $3.465^{\mathrm{f}}$ & $3.080^{d}$ & $0.168^{\mathrm{a}}$ \\
\hline \multirow{6}{*}{7} & \multirow{2}{*}{ ND } & 5 & $41.2^{\mathrm{a}}$ & $13.4^{\mathrm{a}}$ & $6.4^{\mathrm{a}}$ & $0.345^{\mathrm{a}}$ \\
\hline & & 7 & $2.999^{\mathrm{a}}$ & $492^{\mathrm{ab}}$ & $446^{\mathrm{a}}$ & $0.177^{\mathrm{a}}$ \\
\hline & \multirow{2}{*}{$\mathrm{D}$} & 5 & $3.519^{\mathrm{ab}}$ & $633^{\mathrm{b}}$ & $524^{\mathrm{a}}$ & $0,179^{\mathrm{a}}$ \\
\hline & & 7 & $7.451^{\mathrm{bc}}$ & $1.284^{\mathrm{c}}$ & $1.434^{\mathrm{b}}$ & $0.172^{\mathrm{a}}$ \\
\hline & \multirow{2}{*}{ DF } & 5 & $0.11^{\mathrm{a}}$ & $0.21^{\mathrm{a}}$ & $0.03^{\mathrm{a}}$ & $2.006^{\mathrm{b}}$ \\
\hline & & 7 & $2.341^{\mathrm{a}}$ & $415^{\mathrm{ab}}$ & $349^{\mathrm{a}}$ & $0.175^{\mathrm{a}}$ \\
\hline
\end{tabular}

Products with the same letter in the same column do not differ significantly (p>0.05). Letters ordered from lower (a) to higher (f) are mean values for each parameter. LWPC=liquid whey protein concentrate 
Table 4. Stress at rupture $\left(\sigma_{\text {rup }}\right)$ and Young's modulus $\left(E^{\prime}\right)$ of nondefatted (ND), defatted (D) and diafiltered (DF) LWPC thermal gels as a function of $\mathrm{pH}$ and protein mass fraction

\begin{tabular}{|c|c|c|c|c|}
\hline $\mathrm{pH}$ & Gel type & $w($ protein $) / \%$ & $\sigma_{\text {rup }} / \mathrm{kPa}$ & $E^{\prime} / \mathrm{kPa}$ \\
\hline \multirow{6}{*}{4} & \multirow{2}{*}{ ND } & 5 & $(1.39 \pm 0.79)^{\mathrm{ab}}$ & $3.00 \pm 1.77$ \\
\hline & & 7 & $(2.98 \pm 0.87)^{\mathrm{ab}}$ & $5.02 \pm 1.08$ \\
\hline & \multirow{2}{*}{$\mathrm{D}$} & 5 & $(1.30 \pm 0.57)^{\mathrm{a}}$ & $2.16 \pm 0.79$ \\
\hline & & 7 & $(2.98 \pm 0.96)^{\mathrm{ab}}$ & $3.16 \pm 1.72$ \\
\hline & \multirow{2}{*}{$\mathrm{DF}$} & 5 & $(3.36 \pm 0.45)^{\mathrm{ab}}$ & $4.04 \pm 1.21$ \\
\hline & & 7 & $(2.59 \pm 0.99)^{\mathrm{ab}}$ & $5.22 \pm 1.92$ \\
\hline \multirow{6}{*}{7} & \multirow{2}{*}{ ND } & 5 & n.d. & n.d. \\
\hline & & 7 & $(4.20 \pm 1.72)^{\mathrm{b}}$ & $5.49 \pm 2.38$ \\
\hline & \multirow{2}{*}{$\mathrm{D}$} & 5 & n.d. & n.d. \\
\hline & & 7 & $(2.57 \pm 0.60)^{\mathrm{ab}}$ & $3.79 \pm 1.21$ \\
\hline & \multirow{2}{*}{ DF } & 5 & n.d. & n.d. \\
\hline & & 7 & $(2.69 \pm 1.43)^{\mathrm{ab}}$ & $4.46 \pm 1.84$ \\
\hline
\end{tabular}

Mean values with the same letter do not differ significantly $(\mathrm{p}>0.05)$. LWPC=liquid whey protein concentrate, $n . d .=$ not determined

the texture profile analysis (TPA) test (data not shown) had a similar behaviour to $E^{\prime}$. In the case of diafiltered gels this trend was not verified at $\mathrm{pH}=7$, probably due to the stronger repulsion forces between proteins at this $\mathrm{pH}$. The non-defatted gels showed the highest $\sigma_{\text {rup }}$ and $E^{\prime}$ and the defatted gels the lowest values.

Table 4 presents the results obtained by large-strain rheological tests $\left(\sigma_{\text {rup }}\right.$ and $\left.E^{\prime}\right)$. No significant differences were observed for $\sigma_{\text {rup }}$ and for $E$, with the exception of $\sigma_{\text {rup }}$ of defatted samples treated at $\mathrm{pH}=4$ with $5 \%$ protein and non-defatted samples treated at $\mathrm{pH}=7$ with $7 \%$ protein, which showed the lowest and highest values, respectively. Again with the exception of the $\sigma_{\text {rup }}$ of diafiltered sample treated at $\mathrm{pH}=4$ with $7 \%$ protein, in all cases, the increase in protein content led to higher average values. It is not possible to observe a common pattern associated with the effect of $\mathrm{pH}$ variation. In some cases, the increase in the $\mathrm{pH}$ led to an increase in $\sigma_{\text {rup }}$ and $E^{\prime}$ (non-defatted samples treated at $\mathrm{pH}=7$ with $7 \%$ protein) while in defatted and diafiltered samples $\sigma_{\text {rup }}$ and $E$ 's showed opposite trends. Taking in account the variability of the obtained results, it can be considered that this methodology, with the conditions used, does not provide valuable information when compared to small-strain rheological tests.

\section{Water holding capacity of thermal gels}

Table 2 also presents the average values of water holding capacity (WHC) for each gel type according to $\mathrm{pH}$ and protein mass fraction. At the same protein mass fraction, the non-defatted gels had a higher water holding capacity than the defatted and diafiltered gels. It has been noted that the presence of lipids may diminish hydrophobic proteinprotein interactions, since they also participate in this type of interaction with proteins $(34,47)$. However, Sodini et al. (48) pointed out that when fat is present in significant amounts in the formulation, it may also participate in the formation of the gel structure, contributing towards reduc- ing syneresis. This phenomenon can be improved by homogenisation during gel production, because it reduces the size of the fat globules, increasing their surface area and enhancing their interaction with proteins. From our results, it was observed that lipids, which are present in higher mass fractions in non-defatted products, may establish hydrophobic interactions with proteins that lead to the formation of a gel structure with higher capacity to retain water, which confirms the results obtained for rheological properties $\left(G{ }^{\prime}\right.$ and $G^{\prime \prime}$ ).

It was also observed that an increase in protein mass fraction leads to a decrease in syneresis. The number of hydrophobic groups and cysteine residues available to react increases with protein mass fraction, and the formation of a more effective gel matrix is possible $(6,42)$. As already mentioned, at lower protein mass fraction, protein intramolecular interactions predominate and there is a greater tendency to form protein aggregates instead of a gel structure (34). In this case, the aggregates do not have the capacity to retain water and syneresis increases. It was also observed that close to the isoelectric point of whey proteins, the water holding capacity decreases, as the protein hydrophobic intramolecular forces are more effective than the protein intermolecular forces ( $\mathrm{S}-\mathrm{H}$ bonds), leading to a more open matrix expelling more water (49). However, the increase in the protein mass fraction leads to higher values of $\sigma_{\text {rup }}$ and $E^{\prime}$. At $\mathrm{pH}=7$ and low protein mass fractions, no selfsupporting gel was formed, regardless of the type of LWPC. In this case, the attractive forces between proteins were not sufficient to produce a solid network, and the continuous phase was still a liquid. Only with higher protein mass fractions, the balance between protein-protein interactions (attractive forces) and protein-water interactions (repulsive forces) is more effective, meaning that the gel structure has the capacity to retain water more efficiently.

\section{Thermal gel microstructure}

It is well recognised that the structure of foods greatly affects their various properties, including texture, functionality and appearance. The microstructure of thermal gels produced by LWPC is shown in Fig. 3.

It was noted that the gels consist of a coarse particulate network of protein particles linked together in clusters, chains and strands. This type of organisation is also identified in the microstructure of whey protein gels produced by WPC (50) and acid milk gels (51). The network has pores or void spaces in which the aqueous phase is confined. In fat-containing products (non-defatted), especially at higher protein mass fractions, a continuous gel matrix was observed that obscures the finer details of the aggregates, clusters and strands, although small pores can be identified. The presence of higher mineral contents in the gels with higher protein mass fractions (Table 2) may also contribute to protein aggregation and the reduction of pores.

In the non-defatted gels with lower protein mass fraction $(5 \%)$ at $\mathrm{pH}=4$, a reticulate gel microstructure was observed, demonstrating their fragility and lower water holding capacity. It was also observed that the diameter of the pores varies considerably, with larger pores found in gels made with defatted and diafiltered LWPC products. 


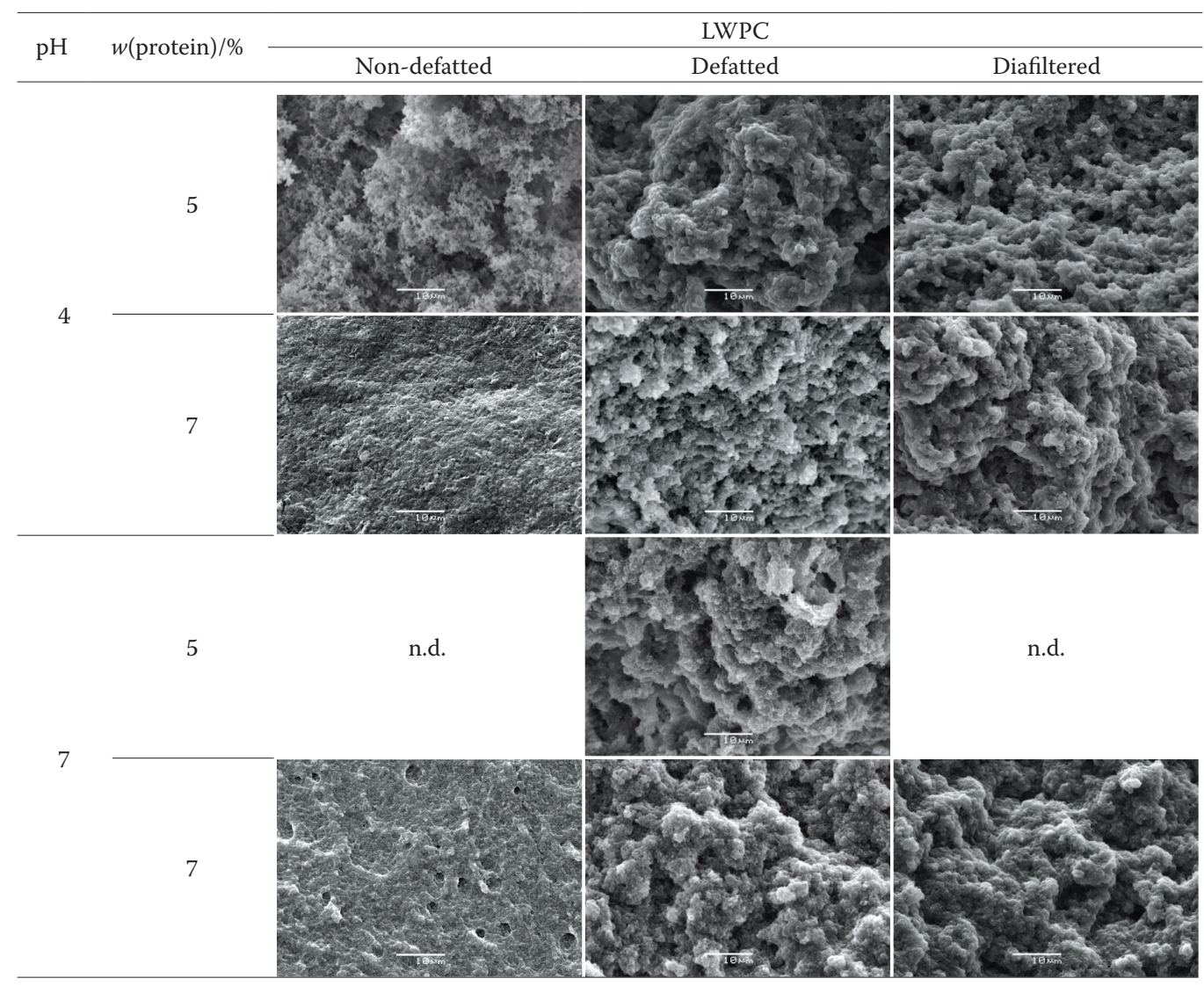

Fig. 3. Scanning electron micrographs $(\times 2000)$ showing effects of $\mathrm{pH}$ and protein mass fraction on the microstructure of thermal gels of liquid whey protein concentrates (LWPC). Bar length is $10 \mu \mathrm{m}$. n.d.=not determined

In both cases, regardless of the protein mass fraction, no significant differences were found in the granulated microstructure, and the presence of small protein structures (aggregates with a spherical shape), linked together in bigger structures (clusters), was evident. The former are formed by intramolecular protein interactions, and the latter by intermolecular interactions among aggregates $(52,53)$. If the $\mathrm{pH}$ is increased, no differences are observed in the gel microstructure. It is not clear from scanning electron microscopy (SEM), if small pores were formed at $\mathrm{pH}=7$, which would result in a more homogeneous (less granulated) gel network. This feature could justify the results obtained for WRC, indicating that $\mathrm{pH}$ values far from the isoelectric point of proteins lead to the production of a gel network with a higher capacity to retain solvents $(52,53)$.

\section{Conclusions}

Liquid whey protein concentrate (LWPC) is a suitable primary raw material for producing heat-induced gels. This may have an important impact on food characteristics, such as improved flavour and colour, and lower production costs. Depending on the process used to manufacture LWPC and gels, products with specific chemical and rheological properties were achieved, which can be selected according to the desired food application. Nondefatted LWPC produced stronger heat-induced gels with a continuous microstructure network, whereas defatted and diafiltered LWPC produced gels in which the microstructure had a more open matrix network formed by aggregates. Increasing the protein mass fraction improved the water holding capacity and viscoelastic behaviour of gels. However, $\mathrm{pH}$ had a significant influence on gelation by determining the balance of protein attraction and repulsion forces. These applications allow for the production of high value and highly nutritional dairy products as a low cost alternative to the use of powdered products. Other gelation modes were also evaluated and are presented elsewhere. This possibility represents another important feature of LWPC that can be applied in the food industry to meet the modern consumer demand for both safety and satisfaction.

\section{Acknowledgements}

This work was supported by program CENTRO2020, Operation Code CENTRO-01-0246-FEDER-000020, grant no. 6644: Lab2factory, Coimbra, Portugal.

\section{References}

1. Smithers GW. Whey and whey proteins - From 'gutter-to-gold'. Int Dairy J. 2008;18:695-704.

https://doi.org/10.1016/j.idairyj.2008.03.008

2. Smithers GW. Whey-ing up the options - Yesterday, today and tomorrow. Int Dairy J. 2015;48:2-14.

https://doi.org/10.1016/j.idairyj.2015.01.011 
3. Patel S. Functional food relevance of whey protein: A review of recent findings and scopes ahead. J Funct Foods. 2015;19:308-19. https://doi.org/10.1016/j.jff.2015.09.040

4. Díaz O, Pereira CD, Cobos Á. Applications of whey protein concentrates and isolates in food industry. Alimentaria. 2009;400:10815 (in Spanish).

5. Zayas JF. Functionality of proteins in food. Berlin, Germany: Springer-Verlag; 1997. pp. 310-66.

6. Singh H. Milk proteins - Functional properties. In: Roginski H, Fuquay JW, Fox PF, editors. Encyclopedia of dairy sciences. London, UK: Academic Press (Elsevier Science); 2002. pp. 1976-82. https://doi.org/10.1016/B0-12-227235-8/00332-1

7. Mangino ME. Gelation of whey protein concentrates. Food Technol. 1992;46:114-7.

8. Boye JI, Alli I, Ramaswamy H, Raghavan VGS. Interactive effects of factors affecting gelation of whey proteins. J Food Sci. 1997;62:57-65.

https://doi.org/10.1111/j.1365-2621.1997.tb04368.x

9. Ramos ÓL, Pereira JO, Silva SI, Amorim MM, Fernandes JC, Lopes-da-Silva JA, et al. Effect of composition of commercial whey protein preparations upon gelation at various $\mathrm{pH}$ values. Food Res Int. 2012;48:681-9.

https://doi.org/10.1016/j.foodres.2012.06.004

10. Mulvihill DM, Kinsella JE. Gelation of $\beta$-lactoglobulin: Effects of sodium chloride and calcium chloride on the rheological and structural properties of gels. J Food Sci. 1988;53:231-6. https://doi.org/10.1111/j.1365-2621.1988.tb10216.x

11. Urbonaite V, van der Kaaij S, de Jongh HHJ, Scholten E, Ako K, van der Linden E, Pouvreau L. Relation between gel stiffness and water holding for coarse and fine-stranded protein gels. Food Hydrocolloid. 2016;56:334-43.

https://doi.org/10.1016/j.foodhyd.2015.12.011

12. Joseph MSB, Mangino ME. The effect of milk fat globule membrane protein on the foaming and gelation properties of $\beta$-lactoglobulin solutions and whey protein concentrates. Aust J Dairy Technol. 1988;43:9-11.

13. Yamul DK, Galmarini MV, Lupano CE, Zamora MC. Whey protein concentrate gels with different sucrose content: instrumental texture measurements and sensory perception. Int Dairy J. 2013;28:24-31.

https://doi.org/10.1016/j.idairyj.2012.08.002

14. Zhang Z, Arrighi V, Campbell L, Lonchamp J, Euston SR. Properties of partially denatured whey protein products: Formation and characterisation of structure. Food Hydrocolloid. 2016;52:95-105. https://doi.org/10.1016/j.foodhyd.2015.06.009

15. Ji Y, Lee SK, Anema SG. Characterisation of heat set milk protein gels. Int Dairy J. 2016;54:10-20.

https://doi.org/10.1016/j.idairyj.2015.10.003

16. Purwanti N, Smiddy M, van der Goot AJ, de Vries R, Alting A, Boom R. Modulation of rheological properties by heat-induced aggregation of whey protein solution. Food Hydrocolloid. 2011;25:1482-9.

https://doi.org/10.1016/j.foodhyd.2011.02.027

17. Purwanti N, Moerkens A, van der Goot AJ, Boom R. Reducing the stiffness of concentrated whey protein isolate (WPI) gels by using WPI microparticles. Food Hydrocolloid. 2012;26:240-8. https://doi.org/10.1016/j.foodhyd.2011.05.015

18. Sağlam D, Venema P, de Vries R, van den Berg M, van der Linden E. Whey protein particles modulate mechanical properties of gels at high protein concentrations. Food Hydrocolloid. 2014;38:163-71. https://doi.org/10.1016/j.foodhyd.2013.11.015

19. Kinsella JE, Rector DJ, Phillips LG. Physicochemical properties of proteins: Texturization via gelation, glass and film formation. In: Yada RY, Jackman RL, Smith JL, editors. Protein structure-function relationship in foods. Boston, MA, USA: Springer Science+Business Media, LLC; 1994. pp. 1-21. https://doi.org/10.1007/978-1-4615-2670-4_1

20. Morr CV, Foegeding EA. Composition and functionality of commercial whey and milk protein concentrates and isolates: a status report. Food Technol. 1990;44:100-12.

21. Bryant $\mathrm{CM}, \mathrm{McClements} \mathrm{DJ}$. Influence of $\mathrm{NaCl}$ and $\mathrm{CaCl}_{2}$ on cold-set gelation of heat-denatured whey protein. J Food Sci. 2000;65:801-4. https://doi.org/10.1111/j.1365-2621.2000.tb13590.x

22. Cavallieri ALF, Costa-Netto AP, Menossi M, Da Cunha RL. Whey protein interactions in acidic cold-set gels at different $\mathrm{pH}$ values. Lait. 2007;87:535-54. https://doi.org/10.1051/lait:2007032

23. Lee WJ, Lucey JA. Formation and physical properties of yogurt. Asian-Aust J Anim Sci. 2010;23:1127-36.

https://doi.org/10.5713/ajas.2010.r.05

24. NP 470. Milk. Acidity determination. Technical Commission 32. Lisbon, Portugal: IPQ - Portuguese Institute of Quality; 1983 (in Portuguese).

25. NP 701. Yogurt. Acidity determination. Technical Commission 32. Lisbon, Portugal: IPQ - Portuguese Institute of Quality; 1982 (in Portuguese).

26. AOAC Official Method 16.032. Total solids, Method I - Official final action. Rockville, MD, USA: AOAC International; 1980.

27. ISO 8968-1:2001. Milk - determination of nitrogen content - Part 1: Kjeldahl method. Geneva, Switzerland: International Organization for Standardization (ISO); 2001.

28. NP 469. Milk. Fat content determination. Gerber method. Technical Commission 32. Lisbon, Portugal: IPQ - Portuguese Institute of Quality; 2002 (in Portuguese).

29. NP 1923. Yogurt. Fat content determination. Gerber method. Technical Commission 32. Lisbon, Portugal: IPQ - Portuguese Institute of Quality; 1987 (in Portuguese).

30. Dairy products. Official Methods of Analysis, vol. II. Arlington, TX, USA: Association of Official Analytical Chemists (AOAC); 1995.

31. Henriques MHF, Gomes DMGS, Pereira CJD, Gil MHM. Effects of liquid whey protein concentrate on functional and sensorial properties of set yogurts and fresh cheese. Food Bioprocess Tech. 2013;6:952-63.

https://doi.org/10.1007/s11947-012-0778-9

32. STATISTICA, v. 12, StatSoft, Inc, Tulsa, OK, USA; 2013. Available from: http://www.statsoft.com.

33. Sullivan ST, Khan SA, Eissa AS. Whey proteins: functionality and foaming under acidic conditions. In: Onwulata CI, Huth PJ, editors. Whey processing, functionality and health benefits. Iowa, USA: Willey-Blackwell; 2008. pp. 99-132. https://doi.org/10.1002/9780813803845.ch5

34. Zayas JF, editor. Functionality of proteins in food. Berlin, Germany: Springer-Verlag, 1997.

https://doi.org/10.1007/978-3-642-59116-7

35. Oakenfull DG, Pearce RJ, Burley RW. Protein gelation. In: Damodaran S, Paraf A, editors. Food proteins and their applications. New York, NY, USA: Marcel Dekker Inc.; 1997. pp. 111-42.

36. Casper JL, Wendorff WL, Thomas DL. Functional properties of whey protein concentrates from caprine and ovine specialty cheese wheys. J Dairy Sci. 1999;82:265-71. https://doi.org/10.3168/jds.S0022-0302(99)75232-X

37. Tang Q, McCarthy OJ, Munro PA. Oscillatory rheological study of the effects of $\mathrm{pH}$ and salts on gel development in heated whey protein concentrate solutions. J Dairy Res. 1995;62:469-77. https://doi.org/10.1017/S0022029900031162

38. Bordenave-Juchereau S, Almeida B, Piot JM, Sannier F. Effect of protein concentration, $\mathrm{pH}$, lactose content and pasteurization on thermal gelation of acid caprine whey protein concentrates. J Dairy Res. 2005;72:34-8. https://doi.org/10.1017/S0022029904000482 
39. Pintado ME, Lopes da Silva JA, Malcata FX. Comparative characterization of whey protein concentrates from ovine, caprine and bovine breeds. LWT - Food Sci Technol. 1999;32:231-7. https://doi.org/10.1006/fstl.1999.0531

40. Lorenzen PC, Schrader K. A comparative study of the gelation properties of whey protein concentrate and whey protein isolate. Lait. 2006;86:259-71.

https://doi.org/10.1051/lait:2006008

41. Heino AT, Ussi-Rauva JO, Rantamäki P, Tossavainen O. Functional properties of native and cheese whey protein concentrate powders. Int J Dairy Technol. 2007;60:277-85. https://doi.org/10.1111/j.1471-0307.2007.00350.x

42. Sanmartín B, Díaz O, Rodríguez-Turienzo L, Cobos Á. Properties of heat-induced gels of caprine whey protein concentrates obtained from clarified cheese whey. Small Rumin Res. 2015;123:142-8. https://doi.org/10.1016/j.smallrumres.2014.10.014

43. Díaz O, Pereira CD, Cobos Á. Rheological properties and microstructure of heat-induced gels of ovine whey protein concentrates obtained from clarified cheese whey. Milchwissenschaft. 2006;61:193-6.

44. Blecker C, Paquot M, Deroanne C. Gelling properties of whey proteins after enzymic fat hydrolysis. J Food Sci. 2000;65:561-3. https://doi.org/10.1111/j.1365-2621.2000.tb16048.x

45. Schmidt RH, Packard VS, Morris HA. Effect of processing on whey protein functionality. J Dairy Sci. 1984;67:2723-33. https://doi.org/10.3168/jds.S0022-0302(84)81630-6

46. Rosenthal AJ. Contact stresses in gelatin spheres under compressive die loading. J Texture Stud. 2016;47:457-60. https://doi.org/10.1111/jtxs.12196
47. Morr CV. Improving the texture and functionality of whey protein concentrate. Food Technol. 1992;46:110-13.

48. Sodini I, Lucas A, Oliveira MN, Remeuf F, Corrieu G. Effect of milk base and starter culture on acidification, texture, and probiotic cell counts in fermented milk processing. J Dairy Sci. 2002;85:2479-88. https://doi.org/10.3168/jds.S0022-0302(02)74330-0

49. Kitabatake N, Doi E. Denaturation and texturization of food protein. In: Kokini JL, Ho CT, Karwe MV, editors. Food extrusion science and technology. New York, NY, USA: Marcel Dekker Inc.; 1992. pp. 361-71.

50. Aguilera JM. Gelation of whey proteins. Food Technol. 1995;49:83-9.

51. Kalab M, Allan-Wojtas P, Phipps-Todd BE. Development of microstructure in set-style nonfat yoghurt - a review. Food Microstructure. 1983;2:51-66. Available from: https://pdfs.semanticscholar.org/8c49/644f3961cdbd4e6e9e8744e6d21a43fc40b6.pdf

52. Yamul DK, Lupano CE. Properties of gels from whey protein concentrate and honey at different pHs. Food Res Int. 2003;36:25-33. https://doi.org/10.1016/S0963-9969(02)00104-7

53. Chantrapornchai W, McClements DJ. Influence of $\mathrm{NaCl}$ on optical properties, large-strain rheology and water holding capacity of heat-induced whey protein isolate gels. Food Hydrocolloid. 2002;16:467-76. https://doi.org/10.1016/S0268-00X(01)00124-2 